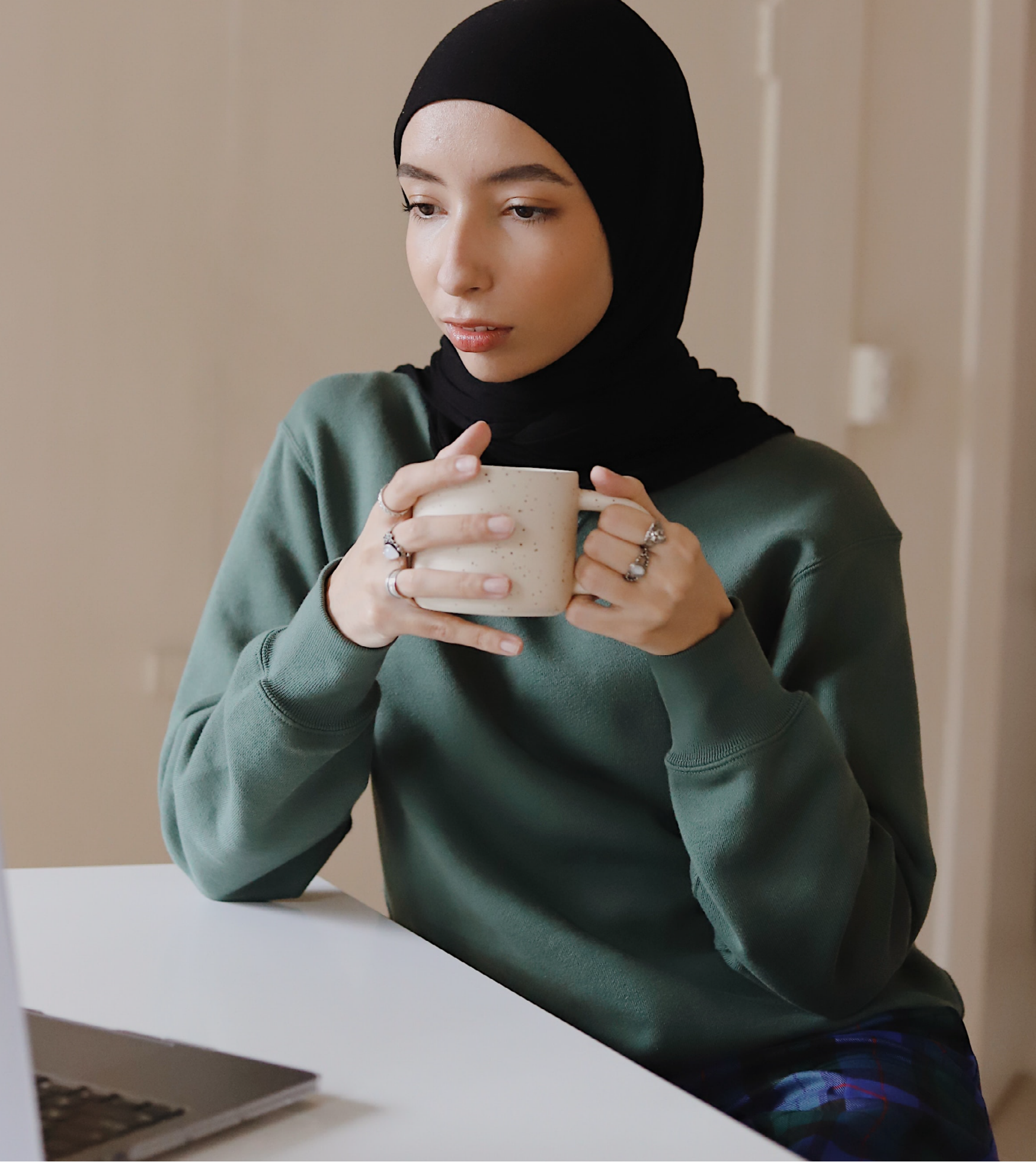

\title{
Reach Us
}

Lantai Dasar, Laboratorium Kimia, Program Studi Pendidikan Kimia, Jurusan Kimia,

Fakultas Matematika dan Ilmu Pengetahuan Alam, Universitas Negeri Padang.

Jl. Prof. Dr. Hamka, Air Tawar Barat, Padang Utara, Padang, Sumatera Barat, Indonesia. 25171

Photo in front cover credit to Malte Helmhold on Unsplash.

Photo in back cover credit to Good Faces on Unsplash.

More details please read inside this issue.

\section{Accredited by: \\ Indexed Google Scholar $\mathrm{C}$ garuda $\sqrt{2}$ ResearchGate

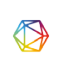 Dimensions \\ âinta 5) WorldCat \\ Acrosat: ${ }^{\prime}$ ic Search}

\section{EKJ Edukimia}

Your trusted platform to publish Chemistry Education articles.
e-ISSN: 2502-6399

Contact us:

edukimiaofcjournal@gmail.com

Visit our Bio.Link or our official website for more details:

https://edukimia.bio.link or http://edukimia.ppj.unp.ac.id/ojs/index.php/edukimia 